DOI: https://doi.org/10.32838/2523-4803/70-4-29

УДК 339.13:658:005.12

\title{
Трішкіна Н.I.
}

кандидат економічних наук, доцент,

Хмельницький торговельно-економічний коледж

Київського національного торговельно-економічного університету

\section{Trishkina Nina}

Khmelnytsky College of Trade and Economics

Kyiv National University of Trade and Economics

\section{КОНКУРЕНТОСПРОМОЖНІСТЬ ПІДПРИЕМСТВА ЯК ОДНА ЗІ СТРАТЕГІЧНИХ ЦІЛЕЙ ПІДПРИСМСТВА}

\begin{abstract}
У статті розглянуто визначальні чинники конкурентоспроможності підприємства, згруповано та охарактеризовано основні чинники, які визначають конкурентоспроможність підприємства на споживчому ринку. Запропоновано критерії та напрями оцінки конкурентоспроможності підприємства та систему показників оцінки конкурентоспроможності підприсмства. Проаналізовані основні види ресурсів, щзо використовуються на підприємствах $і$ на яких застосовано виробничо-торговельний ланцюг. Зроблено висновок, щзо на вітчизняних підприємствах необхідно значно підняти рівень аналітичної роботи усіх сфер діяльності, створити сучасну не тільки облікову, а й аналітично-прогностичну інформаційну систему і мати відповідне інформаційне, методичне, технічне та кадрове забезпечення. Запропоновано основні складники стратегічного потенціалу підприємства, які визначають його потениійні можливості.
\end{abstract}

Ключові слова: виробництво, конкурентоспроможність, підприємство, середовище, споживач, стратегічні иілі.

Постановка проблеми. Ринкова система господарювання, яка існує в Україні, зумовлює зміну форм та методів управління економікою підприємства, вимагає нових підходів до визначення місця та ролі підприємства в розвитку суспільного виробництва.

Досвід роботи виробничих підприємств в умовах ринкової економіки, який накопичено в промислово розвинених країнах, не можна автоматично перенести на управління економічними процесами в Україні. Виникає необхідність його адаптації з урахуванням специфіки сучасного етапу розвитку економіки в Україні та менталітету господарюючих суб'єктів.

Усі комерційні підприємства діють у конкретному ринковому середовищі. У всіх підприємств одна головна мета - одержання прибутку. Одним учасникам ринку досягання зазначеної мети тією чи іншою мірою вдається, а іншим - ні. Такі реалії будь-якого ринку. Здатність підприємств домагатися своїх цілей в умовах ринку, на якому з аналогічними цілями діють інші підприємства, характеризуються поняттям «конкурентоспроможність» як для підприємства, так і для продукції, яку вони виготовляють.

Конкурентоспроможність підприємства - це багатоаспектна економічна категорія, яка є головним критерієм оцінки ефективності виробництва продукції, виконання робіт або надання послуг, а також показником ефективності системи управління суб' єктом господарювання.
Аналіз останніх досліджень і публікацій. Фундаментальним дослідженням питань оцінювання конкурентоспроможності продукції здебільшого присвячено праці зарубіжних авторів: Д. Рікардо, Є. Хекшера, Б. Оліна, М. Портера, I. Ансоффа, М. Альберта, С.М. Лі, Ф. Котлера, Р. Монкріфа, Ч. Фатрелла та ін. Теоретичні і практичні аспекти досліджуваної проблеми знайшли відображення в роботах відомих вітчизняних учених-економістів: В.Я. Кардаша, С.Ф. Покропивного, В.В. Липучка, А.П. Дудяка, С.Я. Бугіля, В.Д. Кучеренка, Н.Б. Ткаченко та ін.

Незважаючи на значну кількість робіт, присвячених проблемі конкурентоспроможності підприємства, і визнану значимість даної проблеми, сьогодні не існує єдиної теорії конкурентоспроможності підприємств. У науковій літературі сформувалося доволі широке теоретико-методологічне трактування категорії «конкурентоспроможність підприємства», що спричинено iii багатоаспектністю. Водночас окремі складники цієї багатопланової проблеми є дискусійними і потребують подальшого дослідження.

Формулювання цілей статті. Метою статті $\epsilon$ дослідження основних чинників, які визначають конкурентоспроможність підприємства на споживчому ринку, формування критеріїв та напрямів оцінки конкурентоспроможності підприємства та системи показників оцінки конкурентоспроможності. 
Виклад основного матеріалу. Конкурентоспроможність підприємства зумовлює значна кількість чинників. Вони різні за своєю природою, характером, сферою, ступенем і тривалістю впливу.

Перш за все на конкурентоспроможність будь-якого підприємства впливають зовнішні чинники. Вони являють собою елементи середовища, в якому функціонує і здійснює свою діяльність підприємство. Дія цих чинників не залежить від конкретного підприємства, навпаки, під їхнім впливом створюються відповідні умови для розвитку (чи гальмування) сфери матеріально-технічного і товарного обігу. Не менш значний вплив на конкурентоспроможність підприємства здійснюють внутрішні чинники, що мають місце на самому підприємстві.

Серед зовнішніх та внутрішніх чинників $є$ базові (основні) та другорядні. Базові чинники визначають основні напрями діяльності підприємства та їх ефективність, а другорядні можуть коригувати деякі елементи конкурентоспроможності та підвищувати іiі ефективність.

Зовнішні і внутрішні чинники можуть впливати протягом тривалого періоду часу або тимчасово.

За своєю природою чи характером впливу всі зовнішні чинники поділяються на три групи: чинники соціально-економічного характеру, чинники політичного характеру, науково-технічні та технологічні чинники. Кожна група представлена різноманітними чинниками, які водночас $\epsilon$ взаємозалежними і характеризуються значним впливом один на одного (табл. 1).

Конкурентоспроможність підприємства і забезпечення його стабільності значною мірою залежать від загального макроекономічного стану у державі і розвитку ii економіки. Аналіз соціально-економічного розвитку за період переходу до ринкової економіки свідчить про значну нестабільність і глибоку кризу в економіці України, що негативно позначилося на стані виробництва товарів, їх споживанні (падіння рівня доходів населення призвело до суттєвого зменшення обсягу платоспроможного попиту).

Конкурентоспроможність окремого підприємства на певному сегменті товарного чи регіонального ринку виступає як узагальнююча оцінка його конкурентних переваг у питаннях формування ресурсного потенціалу, якості задоволення завдяки цьому ефективності функціонування господарчої системи, які мають місце на момент чи протягом періоду оцінювання.

Основні чинники, які визначають конкурентоспроможність підприємства на споживчому ринку, можна систематизувати за такими групами, як якість задоволення споживчого попиту, ефективність функціонування господарської системи та ресурсний потенціал (табл. 2).

Кожна група чинників розглядає конкретні показники, які характеризують господарсько-фінансову діяльність підприємства.

Перша група чинників характеризує якість задоволення споживчого попиту. До цих чинників слід віднести: обсяг та структуру товарообороту; темп росту товарообороту; широту, глибину та оновленість асортименту; конкурентоспроможність реалізованих товарів; якість торговельного обслуговування; форми та методи торгівлі, завершеність покупок.

До другої групи чинників належать фактори ефективності функціонування господарської системи. Ця група розглядає часткові показники ефективності: рівень комерційної маржі, ефективність використання товарних ресурсів, ефективність використання матеріально-технічної бази, ефективність притягнення капіталу та узагальнюючі показники ефективності, які характеризують рентабельності капіталу, рентабельність обороту, тривалість операційного та фінансового циклів, фінансову стійкість, платоспроможність та ліквідність.

Третя група чинників розглядає фактори ресурсного потенціалу. Ресурсний потенціал характеризується організацією товарозабезпечення, ефективністю укладання угод на закупівлю товарів, місцем розташування торговельного підприємства, обсягом та складом матеріально-технічної бази, обсягом, станом та складом трудових ресурсів, обсягом та джерелами надходження фінансових ресурсів, організацією менеджменту на підприємстві.

Таблиця 1

Визначальні чинники конкурентоспроможності підприємства

\begin{tabular}{|c|l|}
\hline \multicolumn{1}{|c|}{ Група чинників } & \multicolumn{1}{c|}{ Назва чинника } \\
\hline \multirow{4}{*}{ Чинники соціально-економічного характеру } & 1. Рівень державного регулювання економіки \\
& 2. Система оподаткування \\
& 3. Система кредитування \\
& 5. Чисело-валють і склад населення, його територіальний розподіл \\
& 6. Наявні ресурси за видами та рівень їх використання \\
& 7. Конкуренти \\
\hline \multirow{2}{*}{ Чинники політичного характеру } & 1. Політична стабільність у суспільстві \\
& 2. Міжнародне співробітницто та партнерство \\
& 3. Характер і тенденції міжнародної фінансової допомоги і сприяння \\
\hline Науково-технічні та технологічні чинники & 1. Оцінка науково-технічної політики держави \\
& 2. Рівень техніки і технології \\
& 3. Оцінка якості та конкурентоспроможності продукції \\
& 4. Екологізація виробництва тощо \\
\hline
\end{tabular}


Таблиця 2

Основні чинники, які визначають конкурентоспроможність підприсмства на споживчому ринку

\begin{tabular}{|c|c|}
\hline Група чинників & Назва чинника \\
\hline Якість задоволення споживчого & $\begin{array}{l}\text { 1. Обсяг та структура товарообороту попиту } \\
\text { 2. Темпи росту товарообороту } \\
\text { 3. Широта, глибина та оновленість асортименту } \\
\text { 4. Конкурентоспроможність реалізованих товарів } \\
\text { 5. Якість торговельного обслуговування } \\
\text { 6. Аналіз форм та методів торгівлі } \\
\text { 7. Аналіз завершеності покупок }\end{array}$ \\
\hline $\begin{array}{l}\text { Ефективність функціонування } \\
\text { господарської системи }\end{array}$ & $\begin{array}{l}\text { 1. Часткові показники ефективності: } \\
\text { - рівень комерційної маржі } \\
\text { - ефективність використання товарних ресурсів } \\
\text { - ефективність використання трудових ресурсів } \\
\text { - ефективність використання матеріально-технічної бази } \\
\text { - ефективність притягнення капіталу } \\
\text { 2. Узагальнюючі показники ефективності: } \\
\text { - рентабельність капіталу } \\
\text { - рентабельність обороту } \\
\text { - тривалість операційного та фінансового циклів } \\
\text { - фінансова стійкість } \\
\text { - платоспроможність та ліквідність }\end{array}$ \\
\hline Ресурсний потенціал & $\begin{array}{l}\text { 1. Організація товарозабезпечення } \\
\text { 2. Ефективність укладених угод на купівлю товарів } \\
\text { 3. Аналіз місць розташування торговельних } \\
\text { підприємств } \\
\text { 4. Обсяг та склад матеріально-технічної бази } \\
\text { 5. Обсяг, стан та склад трудових ресурсів } \\
\text { 6. Обсяг та джерела надходження фінансових ресурсів } \\
\text { 7. Організація менеджменту на підприємстві }\end{array}$ \\
\hline
\end{tabular}

3 метою завоювання і утримання конкурентних позицій на ринку для підприємства важливою вимогою в обгрунтуванні стратегії і тактики його діяльності $€$ орієнтація на конкретного покупця, на рівень його платоспроможного попиту. В умовах кризового стану в економіці країни, переходу до ринкових відносин посилилася диференціація в рівнях доходів різних груп населення України. Для обгрунтування вибору стратегії розвитку підприємства визначальним чинником $€$ прогнозування платоспроможного попиту тієї категорії покупців, на яку підприємство передбачає орієнтуватися у перспективі.

Платоспроможний попит різних за рівнем доходів груп населення відрізняється за структурою, за вимогами покупців до умов обслуговування, тому задоволення попиту різних груп покупців зумовлює необхідність для підприємства розроблення різних планових заходів із метою поліпшення своїх позицій у конкурентному середовищі.

Стратегія і тактика підприємства повинна формуватися залежно від досягнутого рівня конкурентоспроможності, з урахуванням наявних рентних переваг чи їх відсутності, на основі орієнтації та задоволення потреб і платоспроможного попиту конкретних груп покупців.

Рентні переваги дають можливість підприємству орієнтуватися, головним чином, на обслуговування більш забезпеченої частини населення. Для забезпечення конкурентоспроможності підприємства необхідно перебудувати організацію і технологію обслуговування, вжити заходів щодо вдосконалення асортиментної політики, створення комфортних умов для покупців: обладнання салонів для демонстрації зразків товарів, місця для паркування транспорту тощо. Проєкт такої перебудови підприємства через більш високу окупність капіталу є привабливим для інвесторів і дасть змогу прискорити іiі реалізацію.

Посилення конкурентоспроможності підприємства пов'язане передусім із проведенням більш гнучкої цінової політики, більш ефективним використанням наявних ресурсів витрат обігу, вивченням та застосуванням світового досвіду щодо технологій продажу товарів у кредит та інших шляхів зростання товарообороту.

Конкурентоспроможність не є явищем, притаманним конкретному об' єкту, вона не витікає з його внутрішньої природи, а виявляється тільки за умов порівняння цього об'єкту з іншими. Виходячи із цього, можна стверджувати, що конкурентоспроможність підприємства можливо оцінити шляхом порівняння найбільш суттєвих показників (чинників) їхньої діяльності. Результатом цього порівняння $є$ визначення рівня конкурентоспроможності. Досягнутий в окремий проміжок часу рівень конкурентоспроможності підприємства не може розглядатися як довгострокова характеристика його ринкової позиції незалежно від ефективності його діяльності. Протидія інших суб'єктів господарювання, рішучість та активність їхніх конкурентних стратегій можуть призвести до втрати досягнутої позиції та зниження рівня конкурентоспроможності.

Отже, конкурентоспроможність є вагомим показником стану підприємства як господарчої системи, який 
залежить від багатьох чинників і визначає перспективи подальшого розвитку підприємства, можливість досягнення стратегічних цілей та завдань. Досягнутий в окремий проміжок часу рівень конкурентоспроможності може розглядатися як одна 3 функціональних стратегічних цілей або завдань підприємства.

Виходячи 3 теоретичних основ оцінки конкурентоспроможності підприємства та враховуючи наявну основну інформацію, сформуємо перелік основних критеріїв та показників оцінки конкурентоспроможності.

Основні критерії та напрями оцінки конкурентоспроможності торговельного підприємства наведено у табл. 3.

Для кількісної оцінки конкурентоспроможності необхідно застосовувати, відповідно до визначеного критерію, систему показників. Це дає можливість аналізувати, знаходити резерви іiі вдосконалення, оцінювати і стимулювати працю персоналу, який безпосередньо займається збутом готової продукції.

Кількісна оцінка конкурентоспроможності дає змогу визначити максимальну межу соціальної та економічної ефективності рішення, яке приймається, робити порівняльні оцінки можливих рішень (альтернатив) і вибір найкращого (максимальний прибуток, мінімальні фінансові витрати, мінімальні трудові витрати, прийнятна для покупця ціна споживання та ін.).

Під час визначення показників оцінки і цільових рівнів, тобто критеріїв, слід ураховувати не тільки те, що кожне торговельне підприємство має специфічні умови існування, знаходиться на певному етапі життєвого циклу, а й специфіку його діяльності та того напряму, для якого розробляється система показників.

Разом із тим слід зауважити, що для оцінки конкурентоспроможності підприємства потрібно мати не тільки належне методичне, а й інформаційне забезпечення, зокрема про ринок, із виокремленням груп товарів, за якими спеціалізується підприємство, визначення економічних і технічних параметрів, порівняльну характеристику цих параметрів. Таким чином, оцінювання конкурентоспроможності підприємства займає центральне місце в його діяльності.

Критерії та напрями оцінки конкурентоспроможності підприємства

Таблиця 3

\begin{tabular}{|c|c|}
\hline Напрями діяльності & Критерії та напрями оцінки \\
\hline \multirow{7}{*}{$\begin{array}{l}\text { 1. Виробничо-торговельна } \\
\text { діяльність }\end{array}$} & Обсяг та склад товарообороту \\
\hline & Перелік та обсяг торговельних послуг, що надаються \\
\hline & $\begin{array}{l}\text { Виробнича потужність торговельного підприємства (загальна торговельна площа, } \\
\text { помножена на кількість годин роботи) }\end{array}$ \\
\hline & Стан торговельної мережі (розміщення, доступність) \\
\hline & Обсяг, склад, витрати обігу та їх рівень \\
\hline & $\begin{array}{l}\text { Товарне забезпечення обороту (обсяг надходження товарів, товарні запаси та їх } \\
\text { відповідність нормативам, ритмічність поставки та ін.) }\end{array}$ \\
\hline & $\begin{array}{l}\text { Організація торговельних процесів та обслуговування споживачів, прогресивність } \\
\text { методів обслуговування, характер організації торговельно-технологічних процесів }\end{array}$ \\
\hline \multirow{8}{*}{ 2. Фінансова діяльність } & Обсяг та структура капіталу, його ціна \\
\hline & Рентабельність діяльності та використання капіталу \\
\hline & Фінансове становище та платоспроможність підприємства \\
\hline & Обсяг та склад оборотного капіталу та його використання \\
\hline & Тривалість операційного циклу та його окремих елементів \\
\hline & Структура та напрями використання фінансових ресурсів підприємства \\
\hline & Рівень та ритмічність виплати дивідендів \\
\hline & Обсяг та склад інвестиційних вкладень \\
\hline \multirow{4}{*}{ 3. Кадрова робота } & Забезпеченість робочою силою (укомплектованість штатів та їх відповідність потребам) \\
\hline & Продуктивність та ефективність праці \\
\hline & Рівень заробітної плати та соціальних виплат, його відповідність ринковому рівню \\
\hline & Стабільність складу колективу (плинність кадрів та іiі причини) та ін. \\
\hline \multirow{7}{*}{ 4. Комерційна діяльність } & Асортиментна політика \\
\hline & Цінова політика \\
\hline & Рекламна діяльність \\
\hline & Організація господарських зв’язків, їх стабільність та ефективність \\
\hline & Характер комерційних угод та їх ефективність \\
\hline & Політика формування торговельної надбавки \\
\hline & Конкурентоспроможність реалізованої продукції та ін. \\
\hline \multirow{5}{*}{$\begin{array}{l}\text { 5. Організаційна та управлінська } \\
\text { діяльність }\end{array}$} & Система планування \\
\hline & Оперативне управління \\
\hline & Професійний рівень керівників та спеціалістів \\
\hline & Раціональність організаційної структури \\
\hline & Інформаційне забезпечення, технологія управління та ін. \\
\hline
\end{tabular}


Показники оцінки конкурентоспроможності підприємства

\begin{tabular}{|c|c|c|}
\hline Показник & Зміст показника & Формула розрахунку \\
\hline \multicolumn{3}{|c|}{ Показники оцінки ефективності управління персоналом підприємства } \\
\hline $\begin{array}{l}\text { Загальна сума фонду заробітної плати } \\
\text { (ФОП) }\end{array}$ & $\begin{array}{l}\text { Добуток середньої заробітної плати (Зпс) на } \\
\text { середньосписочну чисельність працівників (Чс) }\end{array}$ & $\Phi O \Pi=3 n c x Y c$ \\
\hline $\begin{array}{l}\text { Рівень коштів на оплату праці, у \% до } \\
\text { товарообороту (Р фоп) }\end{array}$ & $\begin{array}{l}\text { Відношення фонду оплати праці (ФОП) до } \\
\text { товарообороту за період, що аналізується (ТО) }\end{array}$ & $P_{\phi o n}=\frac{\Phi O \Pi}{T O}$ \\
\hline Рівень плинності кадрів (Рnк) & $\begin{array}{l}\text { Відношення кількості звільнених працівників із } \\
\text { різних причин (З3) на середньосписокву кількість } \\
\text { працівників (Чс) }\end{array}$ & $P n \kappa=\frac{33}{4 c} \times 100$ \\
\hline Середня заробітна плата (3nc) & $\begin{array}{l}\text { Відношення фонду оплати праці (ФОП) до } \\
\text { середньоспискової кількості працівників (Чс) }\end{array}$ & $3 n c=\frac{\Phi O \Pi}{4 c}$ \\
\hline \multicolumn{3}{|c|}{ Показники ефективності використання трудових ресурсів } \\
\hline Продуктивність праці (ПП) & $\begin{array}{l}\text { Відношення прибутку на одного працівника } \\
\text { відповідно у звітному (Пз) і базисному (Пб) періодах }\end{array}$ & $\Pi \Pi=\frac{\Pi 3}{\Pi \sigma}$ \\
\hline Прибуток на одного працівника (П од. п) & $\begin{array}{l}\text { Відношення загального прибутку підприємства (Пр } \\
\text { п) до фактичної кількості працюючих (Чф) }\end{array}$ & $\Pi$ По.n $=\frac{\Pi p n}{\Psi \phi} \times 100$ \\
\hline Доход на одного працівника (Д од. п) & $\begin{array}{l}\text { Відношення загального доходу підприємства (Пр п) } \\
\text { до фактичної кількості працюючих (Чф) }\end{array}$ & Дод.n $=\frac{\text { Дрn }}{\text { Чф }} \times 100$ \\
\hline \multicolumn{3}{|c|}{ Показники ефективності використання матеріальних ресурсів } \\
\hline $\begin{array}{l}\text { Основних фондів: } \\
\text { - фондовіддача }(K \phi в)\end{array}$ & $\begin{array}{l}\text { Відношення обсягу товарообороту }(T O) \text { до середньої } \\
\text { вартості основних фондів, що використовуються в } \\
\text { торговельній діяльності підприємства }(C B \text { oф) } \\
\end{array}$ & $K \phi в=\frac{T O}{C B o \phi}$ \\
\hline \multirow{2}{*}{$\begin{array}{l}\text { - фондоємність }(K \phi \epsilon) \\
\text { - товарообороту на одиницю торговельної } \\
\text { площі (TO 1S) }\end{array}$} & $\begin{array}{l}\text { Відношення коефіцієнта } 1 \text { до розрахованого } \\
\text { показника фондовіддачі }(K \phi s)\end{array}$ & $K \phi \epsilon=\frac{1}{K \phi в}$ \\
\hline & $\begin{array}{l}\text { Відношення товарообороту підприємства (ТО) } \\
\text { до розмірів торговельної площі підприємства, що } \\
\text { аналізується (Sпл) }\end{array}$ & $T O 1 S=\frac{T O}{\operatorname{Sn} \Omega}$ \\
\hline $\begin{array}{l}\text { Обігових фондів: } \\
\text { - коефіцієнт оборотності } \\
\text { обігових активів (КОоа) }\end{array}$ & $\begin{array}{l}\text { Відношення обсягів реалізації обігових активів (Р) } \\
\text { до середньої суми обігових активів за період, що } \\
\text { аналізується (OA) }\end{array}$ & $K O_{o a}=$ \\
\hline $\begin{array}{l}\text { - період обороту обігових } \\
\text { активів (ПОоа) }\end{array}$ & $\begin{array}{l}\text { Відношення суми обігових активів (ОА) до одноденного } \\
\text { обсягу реалізації товарів за період, що аналізується (Ро) }\end{array}$ & $\Pi O_{o a}=\frac{\overline{O A}}{P_{o}}$ \\
\hline $\begin{array}{l}\text { - рівень рентабельності } \\
\text { обігових активів (РРоа) }\end{array}$ & $\begin{array}{l}\text { Відношення суми прибутку підприємства (П) до } \\
\text { середньої суми обігових активів за період, що } \\
\text { аналізується (OA) }\end{array}$ & $P P_{o a}=\frac{\Pi x 100}{\overline{O A}}$ \\
\hline \multicolumn{3}{|c|}{ Показники ефективності використання фінансових ресурсів } \\
\hline Період обороту капіталу (ПОк) & $\begin{array}{l}\text { Відношення середньої суми капіталу (К) до } \\
\text { одноденного обсягу реалізації товарів за період, що } \\
\text { аналізується (Ро) }\end{array}$ & $\Pi O \kappa=\frac{\bar{K}}{P_{o}}$ \\
\hline $\begin{array}{l}\text { Рівень рентабельності використаного } \\
\text { капіталу (Ррвкк) }\end{array}$ & $\begin{array}{l}\text { Відношення суми прибутку підприємства (П) до } \\
\text { середньої суми капіталу підприємства за період, що } \\
\text { аналізується }(\mathrm{K})\end{array}$ & Ррвкк $=\frac{\Pi x 100}{\bar{K}}$ \\
\hline $\begin{array}{l}\text { Коефіцієнт рентабельності власного } \\
\text { капіталу (Крвлк) }\end{array}$ & $\begin{array}{l}\text { Відношення суми прибутку підприємства (П) до } \\
\text { середньої суми власного капіталу підприємства за } \\
\text { період, що аналізується (CK) }\end{array}$ & Крвлк $=\frac{\Pi x 100}{\overline{C K}}$ \\
\hline Капіталовіддача (Ко) & $\begin{array}{l}\text { Відношення суми реалізації товарів (Р) до середньої } \\
\text { суми капіталу за період, що аналізується (К) }\end{array}$ & $K o=\frac{P}{\bar{K}}$ \\
\hline Капіталомісткість $(K M)$ & $\begin{array}{l}\text { Відношення середньої суми капіталу (К) до суми } \\
\text { реалізації товарів за період, що аналізується (P) }\end{array}$ & $K M=\frac{\bar{K}}{P}$ \\
\hline \multicolumn{3}{|c|}{ Показники оцінки ефективності управління фінансовим станом підприємства } \\
\hline Коефіцієнт автономності $(K a)$ & $\begin{array}{l}\text { Відношення суми власного капіталу (ВК) до суми } \\
\text { активів (А) }\end{array}$ & $K a=\frac{B K}{\bar{A}}$ \\
\hline
\end{tabular}




\begin{tabular}{|c|c|c|}
\hline Показник & Зміст показника & Формула розрахунку \\
\hline Коефіцієнт фінансування $(K \phi)$ & $\begin{array}{l}\text { Відношення суми займаного капіталу (ЗК) до суми } \\
\text { власного капталу (ВК) }\end{array}$ & $K \Phi=\frac{3 K}{B K}$ \\
\hline \multicolumn{3}{|c|}{ Показники оцінки ефективності управління процесом торговельного обслуговування } \\
\hline $\begin{array}{l}\text { Коефіцієнт широти реалізованого } \\
\text { асортименту товарів (Ku) }\end{array}$ & $\begin{array}{l}\text { Відношення фактичної кількості товарних груп } \\
\left(A_{\phi}^{T T}\right) \text { до кількості товарних груп, реалізованого } \\
\text { асортименту }\left(A_{n}^{T T}\right)\end{array}$ & $K_{\amalg I}=\frac{A_{\Phi}^{T \Gamma}}{A_{n}^{T \Gamma}}$ \\
\hline $\begin{array}{l}\text { Коефіцієнт глибини реалізованого } \\
\text { асортименту товарів }(К 2)\end{array}$ & $\begin{array}{l}\text { Відношення фактичної кількості різновидів } \\
\text { товарів }\left(A_{\phi}^{p}\right) \text { до кількості різновидів реалізованого } \\
\text { асортименту }\left(A_{n}^{p}\right)\end{array}$ & $K_{\Gamma}=\frac{A_{\phi}^{p}}{A_{n}^{p}}$ \\
\hline $\begin{array}{l}\text { Коефіцієнт стійкості реалізованого } \\
\text { асортименту }(K c)\end{array}$ & $\begin{array}{l}\text { Відношення кількості різновидів товарів, відсутніх } \\
\text { у магазині на момент перевірки }\left(\mathrm{A}_{\Phi}^{n}\right) \text {, до добутку } \\
\text { кількості перевірок (п) на кількість різновидів } \\
\text { товарів, передбачених асортиментним переліком }(A n)\end{array}$ & $K_{c}=1-\frac{\sum A_{\Phi}^{n}}{n x A_{n}}$ \\
\hline $\begin{array}{l}\text { Коефіцієнт завершеності покупок у } \\
\text { магазині (Кз) }\end{array}$ & $\begin{array}{l}\text { Співвідношення кількості покупців, що придбали } \\
\text { товари }\left(P_{3}\right), \text { до загальної кількості покупців, } \\
\text { що прийшли в магазин протягом періоду, що } \\
\text { аналізується ( } T \text { оп) }\end{array}$ & $K_{3}=\frac{P_{3}}{T_{\text {оп }}}$ \\
\hline
\end{tabular}

У табл. 4 запропоновано систему показників оцінки конкурентоспроможності підприємства. Загальний принцип їх розрахунку полягає у порівнянні результатів діяльності підприємства $з$ використанням матеріальних і трудових ресурсів (показник рівня ефективності використання ресурсів) або з розміром поточних витрат для досягнення цих результатів (показник рівня ефективності витрат).

Як видно з табл. 4, показники оцінки конкурентоспроможності підприємства класифіковано за ознакою походження та умовно поділяються на шість груп:

- показники оцінки ефективності управління персоналом підприємства;

- показники ефективності використання трудових ресурсів;

- показники ефективності використання матеріальних ресурсів;

- показники ефективності використання фінансових ресурсів;

- показники оцінки ефективності управління фінансовим станом підприємства;

- показники оцінки ефективності управління процесом торговельного обслуговування.

Ступінь оцінки конкурентоспроможності підприємства залежить не тільки від якості ії здійснення спеціалістами, а й від тих, що займаються суто комерційною діяльністю (збутом товарів, їх продажем тощо), здійснюють торговельно-технологічні операції та від інших структурних підрозділів підприємства. Тому в табл. 4 виокремлено такі групи показників, як ефективність використання трудових ресурсів, ефективність використання фінансових ресурсів та показники оцінки ефективності управління процесом торговельного обслуговування. Сьогодні більшість підприємств не в змозі робити таку всебічну оцінку конкурентоспроможності свого підприємства, тому, виходячи $з$ реальних умов, слід вибирати найбільш прості показники та методи, але які дають змогу певною мірою її оцінити.
Здійснюючи на підприємстві аналіз його конкурентоспроможності, потрібно розглядати показники не тільки у динаміці, а й у порівнянні з відповідними показниками, які склалися у підприємств-конкурентів, а також у середньому по підприємствах аналогічної спеціалізації. Однак це буде можливе лише за умов створення на підприємствах комп'ютеризованих інформаційних систем, удосконалення статистичної звітності та доступності до неї.

Отже, на вітчизняних підприємствах необхідно значно підняти рівень аналітичної роботи усіх сфер діяльності, створити сучасну не тільки облікову, а й аналітично-прогностичну інформаційну систему i мати відповідне інформаційне, методичне, технічне та кадрове забезпечення.

Розв язання цих проблем дасть змогу підвищити рівень обгрунтування управлінських рішень і поліпшити управлінську діяльність підприємства у цілому.

Для оцінки перспективних можливостей підприємства щодо зростання ефективності функціонування та зміцнення конкурентоспроможності на ринку в сучасній економічній літературі використовуються поняття «стратегічний потенціал» та «конкурентний статус» підприємства.

Визначення стратегічного потенціалу підприємства грунтується на використанні системного підходу до розгляду умов та результатів функціонування підприємства, його ціле визначення. Згідно із цим підходом, підприємство розглядається як система ресурсів, які вступають у взаємодію та зумовлюють досягнуті результати.

Основні види ресурсів, що використовуються на досліджуваних підприємствах і на яких застосовано виробничо-торговельний ланцюг, відображено в табл. 5.

Для підприємств специфічним складником ресурсного потенціалу $є$ товарні ресурси: можливі обсяги та умови закупівлі товарів, встановлені господарські зв'язки з постачальниками, асортимент товарної пропозиції, його широта, глибина, оновлювання і відповідність попиту та ін. 
Основні види ресурсів підприсмств, які досліджувалися

\begin{tabular}{|l|l|}
\hline \multicolumn{1}{|c|}{ Види ресурсів } & \multicolumn{1}{|c|}{ Характеристика ресурсів } \\
\hline Технічні ресурси & $\begin{array}{l}\text { Торговельне обладнання } \\
\text { Складське устаткування } \\
\text { Інвентар }\end{array}$ \\
\hline Кадрові ресурси & $\begin{array}{l}\text { Кваліфікаційний рівень спеціалістів } \\
\text { Демографічний склад робітників } \\
\text { Комунікабельність }\end{array}$ \\
\hline Просторові ресурси & $\begin{array}{l}\text { Характер виробничих приміщень } \\
\text { Tериторія підприємства } \\
\text { Комунікацій } \\
\text { Можливість розширення }\end{array}$ \\
\hline Ресурси організаційної структури системи управління & $\begin{array}{l}\text { Характер та гнучкість керуючої системи } \\
\text { Швидкість проходження керуючих впливів }\end{array}$ \\
\hline Інформаційні ресурси & $\begin{array}{l}\text { Характер інформації про внутрішні можливості підприємства } \\
\text { Характер інформації про зовнішнє середовище }\end{array}$ \\
\hline Фінансові ресурси & $\begin{array}{l}\text { Стан активів } \\
\text { Ліквідність } \\
\text { Можливість і обсяги отримання кредитів та ін. }\end{array}$ \\
\hline
\end{tabular}

Кожний із розглянутих видів ресурсів являє собою сукупність можливостей функціонування підприємства та досягнення стратегічних цілей його діяльності. Потенційні можливості підприємства за найбільш ефективного використання ресурсів характеризують стратегічний потенціал підприємства.

Проведені дослідження виявили, що рівень стратегічного потенціалу підприємства визначається:

- по-перше, складом та сучасним станом системи наявних ресурсів;

- по-друге, ступенем відповідності ресурсного потенціалу стратегічним цілям та завданням підприємства;

- по-третє, спроможністю ресурсного потенціалу забезпечити стійкість господарської системи до впливу зовнішнього середовища та внутрішню гнучкість (адаптованість).

Основними складниками стратегічного потенціалу підприємства, які визначають його потенційні можливості, є:

1. Спроможність до проведення макроекономічного аналізу ситуації в країні та регіоні діяльності.

2. Спроможність до прогнозування змін в обсязі та структурі споживчого попиту (за товарними групами та окремими видами, різновидами товарів).

3. Спроможність до аналізу та прогнозування кон'юнктури ринків, ресурсів та капіталу, розроблення та реалізації ефективних стратегій взаємодії з ринками для залучення необхідних ресурсів.

4. Спроможність до висування та реалізації конкурентоспроможних ідей відносно технології та організації торговельного процесу, здійснення закупівлі товарних ресурсів та формування товарної пропозиції.

5. Спроможність до забезпечення стійкості підприємства до негативних змін у зовнішньому середовищі функціонування за рахунок розроблення та реалізації ефективних захисних стратегій.

6. Спроможність до забезпечення внутрішньої гнучкості підприємства за рахунок використання технологічних новацій, зміни спрямованості, зміни спрямованості мотивацій та стимулювання праці пер- соналу, товарної та регіональної диверсифікації діяльності, оснащення новими основними фондами та ін.

7. Здатність до забезпечення конкурентоспроможності асортименту реалізованих товарів, що потрібно для розширення ринку збуту та збільшення ніші господарювання.

8. Спроможність до підтримки конкурентного статуту підприємства та використання конкурентних переваг у боротьбі за споживача.

9. Спроможність до ефективного використання інвестиційних можливостей щодо розвитку ресурсного потенціалу.

10. Спроможність до забезпечення високої ефективності господарювання за рахунок пошуку та мобілізації невикористаних резервів, підтримки необхідних темпів розвитку.

11. Спроможність адаптації стратегії та тактики діяльності підприємства до умов господарювання, що змінюються.

Посилення конкурентоспроможності підприємства пов'язане передусім із проведенням більш гнучкої цінової політики, більш ефективним використанням наявних ресурсів витрат обігу, вивченням та застосуванням світового досвіду щодо технологій продажу товарів та інших шляхів товароруху і зростання товарообороту.

Висновки. Конкурентоспроможність $є$ вагомим показником стану підприємства як господарчої системи, який залежить від багатьох чинників і визначає перспективи подальшого розвитку підприємства, можливість досягнення стратегічних цілей та завдань. Досягнутий в окремий проміжок часу рівень конкурентоспроможності може розглядатися як одна з функціональних стратегічних цілей (завдань) підприємства. Конкурентоспроможність підприємства визначається не тільки кінцевими результатами діяльності підприємства, а закладається ще на стадії планування й є результатом управлінської діяльності на всіх етапах роботи підприємства. Тому конкурентоспроможність підприємства не можна виміряти якимось одним показником, для чого необхідно формувати систему економічних показників. 


\section{Список літератури:}

1. Полторак В.А. Маркетингові дослідження : навчальний посібник. Київ : Центр навчальної літератури, 2003. 387 с.

2. Остапенко Т.М. Класифікація інструментів (методів) контролінгу витрат. Економіка: реалії часу. Інновації. Інвестииії. Конкурентоспроможність. 2013. № 5(10). С. 125-130.

3. Вовк І.П. Особливості впровадження заходів ресурсозбереження та методика визначення їх ефективності на машинобудівних підприємствах у контексті ресурсономіки. Вісник Сумського державного університету. Серія «Економіка». 2012. № 4. С. 107-117.

\section{References:}

1. Poltorak V.A. (2003) Markety`ngovi doslidzhennya [Marketing Research]: A Textbook. Kyiv: Center for Educational Literature, $387 \mathrm{p}$.

2. Ostapenko T.M. (2013) Klasy'fikaciya instrumentiv (metodiv) kontrolingu vy'trat [Classification of tools (methods) of controlling costs]. Economics: the realities of time. Innovations. Investments. Competitiveness, no. 5(10), pp. 125-130.

3. Vovk I.P. (2012) Osobly'vosti vprovadzhennya zaxodiv resursozberezhennya ta metody'ka vy'znachennya yix efekty 'vnosti na mashy 'nobudivny 'x pidpry'yemstvax v konteksti resursonomiky' [Features of implementation of resourcesaving measures and methods of determining their effectiveness in machine-building enterprises in the context of resource economics]. Visnyk of Sumy State University. Economics series, pp. 107-117.

\section{КОНКУРЕНТОСПОСОБНОСТЬ ПРЕДПРИЯТИЯ КАК ОДНА ИЗ СТРАТЕГИЧЕСКИХ ЦЕЛЕЙ ПРЕДПРИЯТИЯ}

В статье рассмотрены определяющие факторы конкурентоспособности предприятия, сгруппированы и охарактеризованы основные факторы, определяющие конкурентоспособность предприятия на потребительском рынке. Предложены критерии и направления оченки конкурентоспособности предприятия и система показателей оценки конкурентоспособности предприятия. Проанализированы основные виды ресурсов, используемых на предприятиях, и в которых применена производственно-торговая цепь. Сделан вывод о том, что на отечественных предприятиях необходимо существенно поднять уровень аналитической работы всех сфер деятельности, создать современную не только учетную, но и аналитически-прогностическую информационную систему и иметь соответствующее информационное, методическое, техническое и кадровое обеспечение. Предложены основные составляющие стратегического потенииала предприятия, которые определяют его потенциальные возможности.

Ключевые слова: производство, конкурентоспособность, предприятие, среда, потребитель, стратегические иели.

\section{COMPETITIVENESS OF THE ENTERPRISE AS ONE OF THE STRATEGIC GOALS OF THE ENTERPRISE}

The article considers the determining factors of the competitiveness of the enterprise, grouped and characterized the main factors that determine the competitiveness of the enterprise in the consumer market, the criteria and directions of an estimation of competitiveness of the enterprise and system of indicators of an estimation of competitiveness of the enterprise are offered, the basic kinds of the resources used at the enterprises and on which the production and trade chain is applied are analyzed. In order to win and maintain a competitive position in the market for the company an important requirement in justifying the strategy and tactics of its activities is the focus on a particular customer, the level of its effective demand. Under the conditions of the crisis in the country's economy, the transition to market relations, the differentiation in income levels of different groups of the population of Ukraine has intensified. To substantiate the choice of enterprise development strategy, the determining factor is forecasting the effective demand of the category of buyers, which the company intends to focus on in the future. Strengthening the competitiveness of the enterprise is associated, first of all, with a more flexible pricing policy, more efficient use of available resources of circulation costs, study and application of world experience in technologies of selling goods and other routes of trade and growth. Competitiveness is an important indicator of the state of the enterprise as an economic system, which depends on many factors and determines the prospects for further development of the enterprise, the ability to achieve strategic goals and objectives. Achieved in a certain period of time the level of competitiveness can be considered as one of the functional strategic goals (objectives) of the enterprise. It is concluded that domestic enterprises need to significantly raise the level of analytical work in all areas of activity, to create a modern not only accounting but also analytical and forecasting information system and have the appropriate information, methodological, technical and personnel support. The main components of the strategic potential of the enterprise are proposed, which determine its potential capabilities.

Key words: production, competitiveness, enterprise, environment, consumer, strategic goals. 